\title{
ESTIMATES OF PEAK DISCHARGE FROM THE DRAINAGE OF ICE-DAMMED APE LAKE, BRITISH COLUMBIA, CANADA
}

\author{
By Joseph R. Desloges, David P. Jones, ${ }^{*}$ \\ (Department of Geography, University of Toronto, Toronto, Ontario M5S 1A1, Canada) \\ and KARL E. RICKER
}

(K.E. Ricker and Associates, 86811 th Avenue, West Vancouver, British Columbia V7T 2M2, Canada)

\begin{abstract}
The first known occurrence of outburst flooding at Ape Lake, British Columbia, was in October 1984 following the formation of a subglacial tunnel in an ice dam created by Fyles Glacier. Following tunnel closure, the lake refilled in $150 \mathrm{~d}$ and then a second outburst flood occurred in August 1986. During both events, $55 \%$ of the Ape Lake volume or $46 \times 10^{6} \mathrm{~m}^{3}$ was released in less than $24 \mathrm{~h}$ into the $50 \mathrm{~km}$ long, ungauged Noeick River, producing an average discharge of $540 \mathrm{~m}^{3} \mathrm{~s}^{-1}$. Channel and flood-plain erosion, damage to access roads, bridges, a logging camp, and an airstrip were related to the peak or maximum instantaneous discharge. In the absence of direct measurements, and to facilitate planning for future flood events, several independent methods were employed to estimate peak discharge. A modified version of the Clague-Mathews formula and the slope-area method yield consistent estimates which approach $1600 \mathrm{~m}^{3} \mathrm{~s}^{-1}$ near the ice-dam outlet. Attenuation of the flood peak in Noeick River is as high as $25 \%$ in the upper $12 \mathrm{~km}$ due to channel and flood-plain storage. Results using Clarke's (1982) physical-based model suggest lower discharges and may be related to the irregular morphology of Ape Lake. Since Fyles Glacier is in continuous retreat, drainage around the margin of the ice dam which began in the summer of 1987 is expected to continue and no further outburst floods are anticipated.
\end{abstract}

\section{INTRODUCTION}

Glacier outburst floods occur following the sudden release of large volumes of water held in lakes that are dammed by glacier ice. In the western Canadian Cordillera and Alaska, outburst flooding at numerous sites has been documented over the last three decades and, in Alaska alone, there are an estimated 750 additional sites with the potential for similar occurrences (Post and Mayo, 1971). In each case, conditions leading to ice-dam failure and subsequent down-stream flooding are related to glacier and basin hydrology, and the morphology of the glacier with respect to the impounded lake. Due to remote locations of most ice-dammed lakes and subsequent damaging flood events, it is difficult to establish and maintain either lake-basin water-level recorders or down-stream gauging sites in order to estimate peak discharge. The objectives of this paper are: (1) to consider the conditions leading to the first of two occurrences of outburst flooding at Ape Lake in the Coast Mountains of south-western British Columbia; and (2) to compare several methods for estimating peak or maximum instantaneous discharge of outburst events which were required to facilitate planning for future flood episodes.

* Present address: D.P. Jones and Associates, \# 57191 Garden City, Richmond, British Columbia, V6Y 3R5, Canada.

\section{OUTBURST EVENTS AT APE LAKE}

Ape Lake (lat. $52^{\circ} 05^{\prime} \mathrm{N}$., long. $126^{\circ} 10^{\prime} \mathrm{W}$.) lies on the drainage divide between the Noeick and Talchako-Bella Coola watersheds in the Coast Mountains of south-western British Columbia (Fig. 1). The lake is dammed on the west margin by Fyles Glacier, a valley glacier which advanced north-east out of the Monarch Icefield across the headwaters of Noeick River. The accumulation area for Fyles Glacier and Ape Glacier, which also drains into the lake, is about $16 \mathrm{~km}^{2}$ and lies between 1800 and $2700 \mathrm{~m}$ a.s.l. The ablation area covers approximately $9 \mathrm{~km}^{2}$, most of which is associated with the broad lobate snout of the Fyles Glacier ice dam which terminates at an elevation of $1320 \mathrm{~m}$ (Fig. 2a). When filled, drainage from Ape Lake is eastward into Ape Creek and then Talchako River. The maximum lake level of $1395 \mathrm{~m}$ is controlled by a channel incised into plutonic bedrock at the east end of the lake. The lake is $2.2 \mathrm{~km}$ long, has an average width of about $800 \mathrm{~m}$, and covers an area of $2.45 \mathrm{~km}^{2}$ (Fig. 2a).

Two outburst floods are known to have occurred at Ape Lake: the first in October 1984 and the second in August 1986. Figure 2 shows the configuration of Ape Lake and the Fyles Glacier ice dam in 1978 prior to any recorded occurrence of outflow, and in August $19862 \mathrm{~d}$ following the second outburst. The chronology of each event was determined using evidence from several different sources. Prior to the first flood, a survey of Ape Lake, including measurements of water quality, had been undertaken (Gilbert and Desloges, 1987). Available information included: lake bathymetry, summer lake-water temperature profiles, and concentrations of suspended

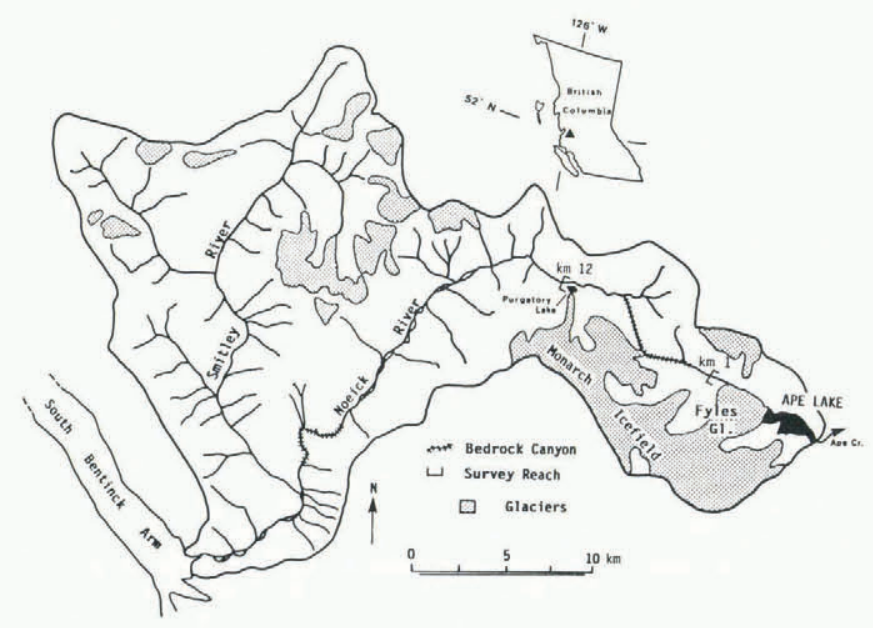

Fig. 1. General location of the Noeick River watershed and Ape Lake. At full pool level, Ape Lake drains east into the Talchako-Bella Coola Rivers via Ape Creek. 


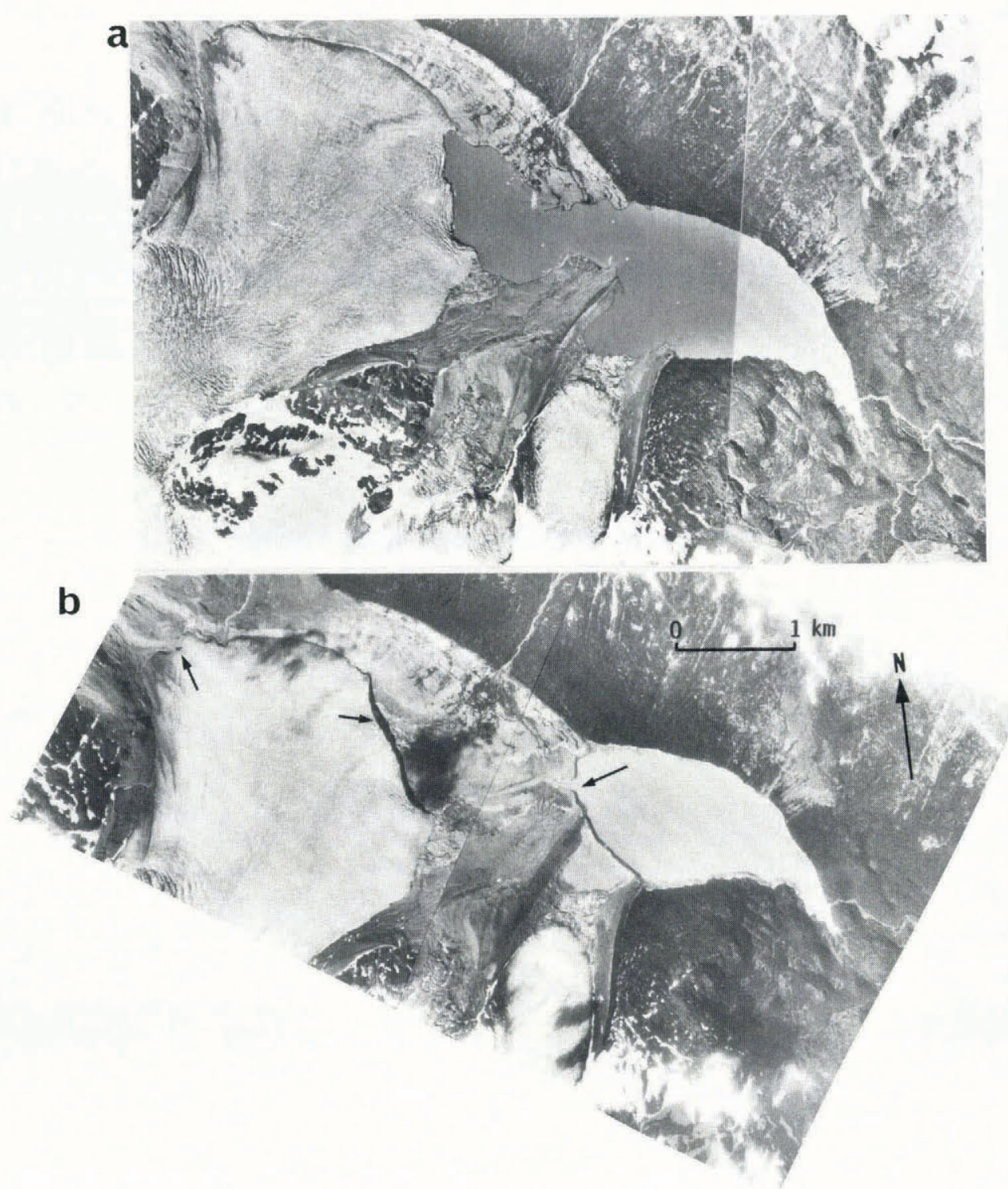

Fig. 2. Configuration of Ape Lake and Fyles Glacier: (a) in August 1978 (British Columbia provincial government photographs BC78125 \#18 and 19), and (b) Ape Lake 1 d after the second draining in August 1986 (photographs by courtesy of Selkirk Remote Sensing). Arrow in middle of basin in (b) points to the breached terminal moraine which separates the larger eastern basin from the ice-dammed west basin. An additional breach formed in the moraine which separates Ape Lake from the embayment at the foot of Ape Glacier. The two additional arrows on Fyles Glacier in (b) point to the inlet and outlet of the subglacial tunnel. Note the amount of recession which has occurred on the northern lake-side margin of Fyles Glacier. The Little Ice Age margin of Fyles Glacier (c. 1860) is visible as a distinct trim line on the north-east side of the lake.

particulate matter at several locations. Additional data about each flood event were collected using eye-witness accounts from loggers, hikers, and aircraft pilots; pre- and post-flood photographs; field surveys of strandlines in the empty basin; and freshly eroded materials in the lake basin and down-stream valley. Following the first flood, air and ground surveys were undertaken in the partly empty lake basin and in the down-stream reaches of Noeick River. These included the establishment of a water-level recorder in Ape Lake, the fixing of permanent survey and photographic benchmarks along valley-bottom logging roads of the Noeick River valley, and the implementation of twice daily aircraft observations of lake and river levels during subsequent melt seasons.

During high lake levels, water leaks beneath Fyles Glacier at an accelerating rate, leading to catastrophic drainage of Ape Lake and flooding of Noeick River. Both outburst events resulted in the release of about $46 \times 10^{6} \mathrm{~m}^{3}$ of water ( $55 \%$ of the lake volume) into a $1.9 \mathrm{~km}$ long ice tunnel beneath Fyles Glacier. The flood peak from the first jökulhlaup on 20 October 1984 passed through the river in at least $24 \mathrm{~h}$ and possibly less. The second event occurred on 1 August 1986, 1 year after the tunnel had sealed and the lake had refilled (Fig. 2). Observations made from the air and in the lower valley show that the peak flow passed through in approximately $20 \mathrm{~h}$. Due to instrument problems, the water-level recorder failed to confirm the timing of the second flood but eye-witness accounts provide sufficient detail for an approximate reconstruction of the flood event.

\section{FLOOD CHRONOLOGY}

The configuration of the two major sub-basins of Ape Lake was a major factor in controlling the release of flood waters during the first event. A submerged moraine, made of mostly a bouldery diamict and marking the former terminal position of Fyles Glacier (Fig. 2b), separates the larger, $70 \mathrm{~m}$ deep, east basin from the more irregular west basin. This moraine influenced the rate and volume of water released from the east basin as shown in the following reconstruction of the first outburst flood (Fig. 3).

It is suspected that only very gradual increases in discharge occurred during the interval $24-48 \mathrm{~h}$ prior to the first flood (cf. Clarke and Waldron, 1984) (stage 0 of Figure 3 ). In the period $12-24 \mathrm{~h}$ before the peak flow, discharge would have increased substantially, resulting in a $5 \mathrm{~m}$ lowering of the lake (stage I of Figure 3). The lake 

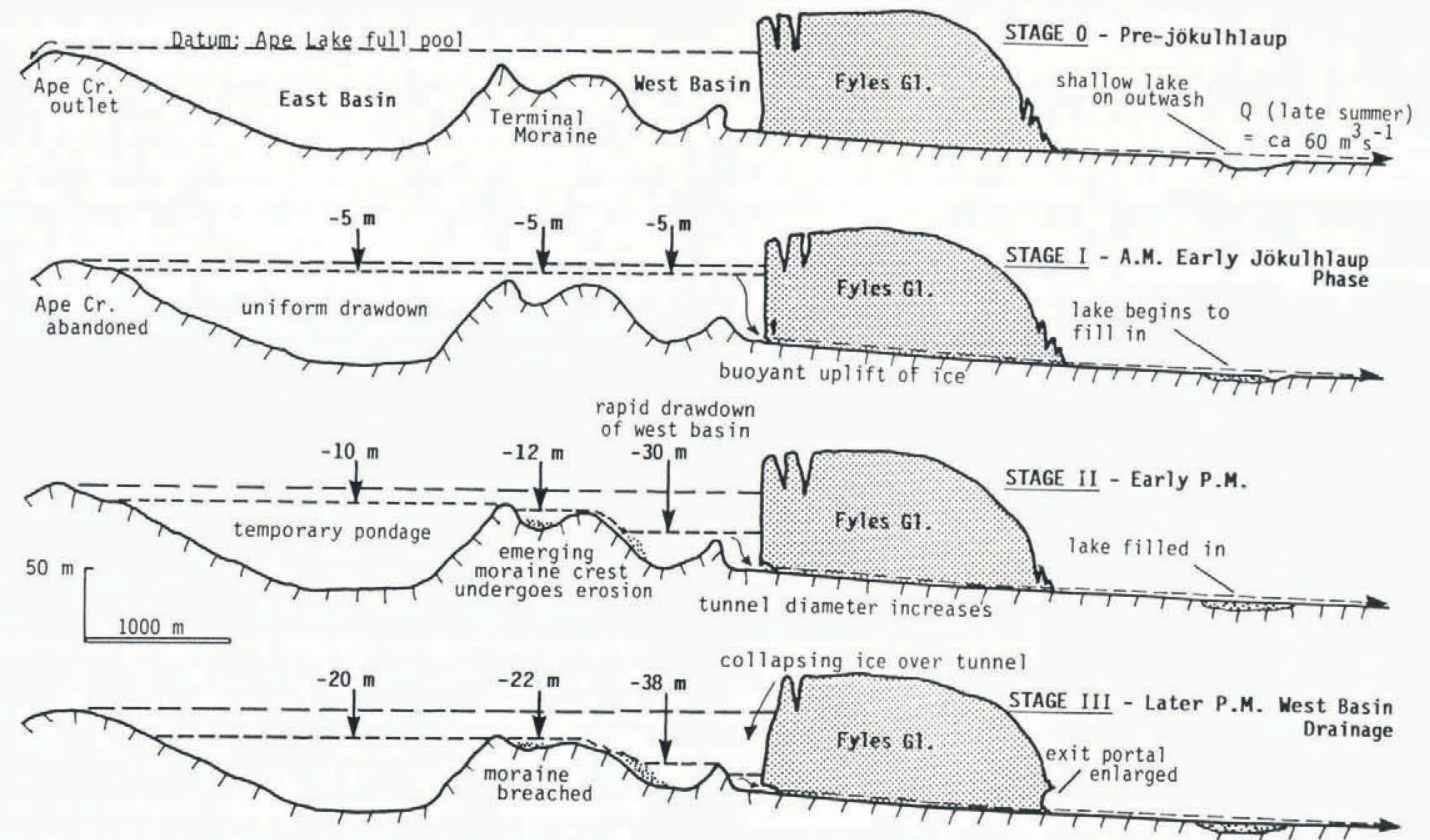

Fig. 3. Chronology of the 20 October 1984 Ape Lake flood (after Jones and others, 1985).

level then dropped below the terminal moraines of Ape and Fyles Glaciers causing, in 1984, temporary ponding of the larger east basin behind the moraine dam while lake lowering continued in the middle and west basins (stage II of Figure 3). It is likely that the dam was breached by continual erosional downcutting as water flowed across the surface. The occurrence of a strandline $10 \mathrm{~m}$ below beach level in the east basin and the limited size of the moraine breach both suggest that erosion of the moraine was sufficiently slow to allow maintenance of higher water levels in the east basin until erosion rates increased to allow discharge of the remaining water. Then, there was an additional $10 \mathrm{~m}$ of lowering in the east basin (stage III of Figure 3). Of the $46 \times 10^{6} \mathrm{~m}^{3}$ of water released during the first flood, about $70 \%$ occurred during the initial $10 \mathrm{~m}$ lowering of the whole basin and complete drainage of the west basin. Then, as the moraine dam was breached and eroded, the remaining $30 \%$ was drained. The presence of the breach in the moraine dam during the second draining in August 1986 meant that the entire $46 \times 10^{6} \mathrm{~m}^{3}$ was involved during stages II and III.

The initial triggering mechanism for the first flood at Ape Lake remains unknown. Two heavy precipitation events occurred in the area: one in early September and the second on 6 and 7 October, 2 weeks prior to the outburst flood. However, the $2 \mathrm{~d}$ return period for these storms at a nearby valley-bottom station was less than 2 years. It is possible that these events increased the level of the lake to its maximum and contributed to the already high, late ablation season, water content of the subglacial zone. These conditions might enhance decoupling of the ice from the underlying terrain.

Following the first flood, Ape Lake began to refill between the winter and summer of 1985 after closure of the tunnel was complete. A predicted closure period of $100-200 \mathrm{~d}$ was estimated assuming that plastic deformation was the most important mechanism affecting closure rates (Jones and others, 1985), although a large amount of collapsed ice at the entrance and exit of the tunnel would have contributed to initial sealing. By 29 July 1985, the lake was full and the eastern outlet was re-activated. The absence of flooding in late 1985 is most likely related to the reduced interval of full lake levels during the summer, tunnel closure, and the contribution of large ice blocks to tunnel sealing (cf. Sturm and others, 1987). The 2 August 1986 flood followed a near-normal July in terms of temperature and precipitation. We suspect that the ice tunnel which developed under the north-east edge of the ice dam was more easily activated this time because of the rapid retreat of the ice margin following the 1984 outburst
(Fig. 2b). Additional retreat of the ice dam after 1986 allowed drainage of Ape Lake around the north edge of Fyles Glacier, and no additional catastrophic floods are anticipated.

\section{ESTIMATING PEAK DISCHARGE}

The peak flood discharge from outburst events will control the extent and degree of valley-bottom erosion and thus the nature of modifications to the channel and flood-plain part of the inundated river. During the October 1984 flood of Noeick River, a fire and logging access road was destroyed in several places: two bridges, an airstrip, and a logging camp were damaged or destroyed; and 200000 newly planted trees that were part of a reforestation project were lost. To facilitate road and bridge repairs and planning for future land-use activities, several methods were employed to estimate the peak outflow discharge. For several reasons, flood damage is expected to differ significantly from that caused by rainstorm- or snow-meltgenerated floods.

Based on reconstructions of both floods, most of the lake volume appears to have drained within $24 \mathrm{~h}$. During the early stages, subglacial leakage probably did not exceed normal inflow to the lake. This is particularly the case for the August event, when melt-water discharge into the lake was at or near the annual maximum. Given a total volume of $46 \times 10^{6} \mathrm{~m}^{3}$ of water drained in $24 \mathrm{~h}$, the average discharge at the tunnel exit would have been $540 \mathrm{~m}^{3} \mathrm{~s}^{-1}$. Several methods were selected for determination of maximum instantaneous discharge.

Measurements made during outburst flooding at several locations in North America, Iceland, and Scandinavia show that the ratio of mean to maximum discharge in ice-dammed lakes of several sizes and configurations varies between about two and six (Fig. 4). Using the estimated mean discharge for Ape Lake, the minimum and maximum peak discharges would be 1080 and $3240 \mathrm{~m}^{3} \mathrm{~s}^{-1}$, respectively.

Clague and Mathews (1973) reviewed the literature concerning the maximum discharge of outburst floods $\left(Q_{\max }\right.$ in $\mathrm{m}^{3} \mathrm{~s}^{-1}$ ) and defined a scale relation with lake volume drained $\left(V\right.$ in $\left.\mathrm{m}^{3} \times 10^{6}\right)$ as an explanatory variable. Recently, several modifications to the Clague-Mathews formula have been used (Jones and others, 1985; Costa, 1988) so as to include observations from more recent events and to exclude the Glacial Lake Missoula datum which represents a late Pleistocene event several orders of magnitude larger than all other floods used to define the relation. The form of the relation proposed by Costa (1988) is: 


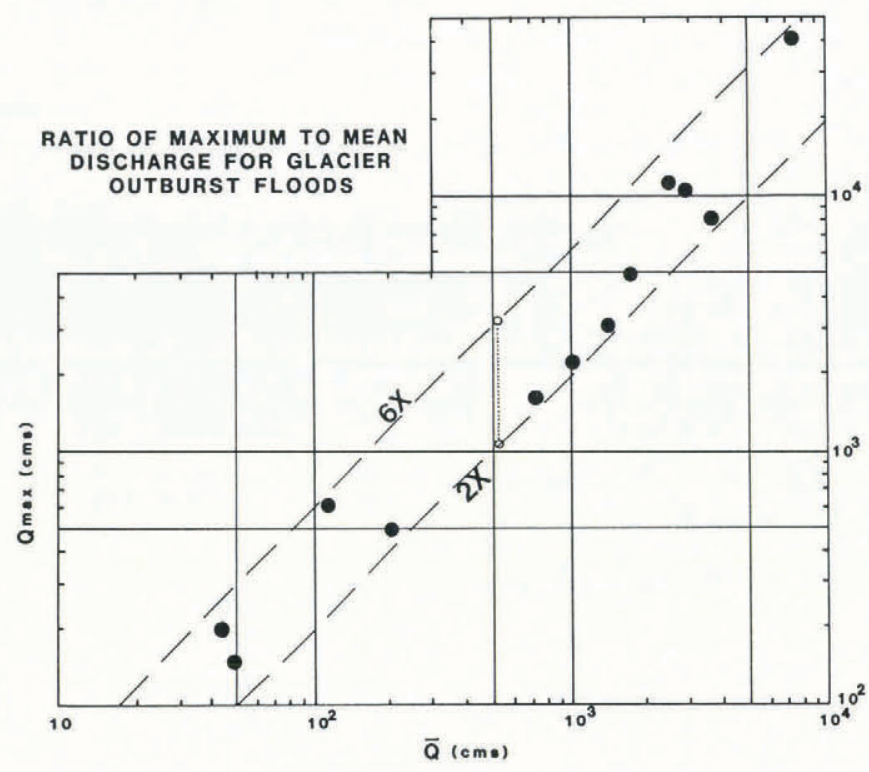

Fig. 4. Plot of mean discharge (Q) versus maximum instantaneous discharges $\left(Q_{\max }\right)$ for several glacier outburst floods. Discriminating lines are two and six times the observed ratios. The vertical dotted line indicates the estimated mean discharge for the 1984 outburst flood at Ape Lake. Outburst discharge data were extracted from Clague and Mathews (1973), Clarke (1982), Clarke and Waldron (1984), Jones and others (1985), and Costa (1988).

$$
Q_{\max }=113 V^{0.64} \quad r^{2}=80 \%
$$

$\mathrm{SE}=0.42 \log -\log$ units.

It has been known for some time by statisticians that these $\log -\log$ relations derived from least-squares regression analysis become biased during back-transformation of the logarithmic coefficients (cf. Miller, 1984), but only recently has it been considered in the physical sciences (Ferguson, 1986). The bias is associated with prediction of $Q_{\max }$ using the antilogged regression (1) in which the geometric mean, not the arithmetic mean, of the dependent variable $\left(Q_{\max }\right.$ in this case) constrains the predictive equation (Ferguson, 1986). Since the geometric mean is always lower than the arithmetic mean, the equation necessarily underestimates peak discharge, in this case by as much as $38 \%$.

An unbiased estimate $\left(a^{\prime}\right)$ for the coefficient $a$ in the power relation:

$$
\log Q_{\max }=a^{\prime}+b \log V
$$

takes the form:

$$
a^{\prime}=a \exp \left(5.302 \times \sigma^{2} / 2\right)
$$

where $\sigma^{2}$ is the standard error of the estimate or residual error for the regression results. The greater the degree of scatter about the regression line, the larger the correction factor. Given $\sigma^{2}=0.42$ in this problem, the correction factor is 1.59 and the new form of the relation is

$$
Q_{\max }=179 V^{0.64} \text {. }
$$

The effect of temporary ponding of the east basin during stage III of the first flood would be to reduce the volume available for discharge to $72 \%$ of the total or $33 \times 10^{6} \mathrm{~m}^{3}$. This would produce an estimated peak discharge and standard error for the first flood of around $1680 \pm$ $380 \mathrm{~m}^{3} \mathrm{~s}^{-1}$.

A third method for estimating maximum discharge (slope-area method) involves the use of the continuity equation:

$$
Q_{\max }=v A
$$

where $v$ is the average cross-sectional flow velocity $\left(\mathrm{m} \mathrm{s}^{-1}\right)$ during peak flow for a cross-section of area $A\left(\mathrm{~m}^{2}\right)$. Two uniform, straight reaches of Noeick River through which the entire water volume was conveyed during the first flood were selected at distances of 1 and $12 \mathrm{~km}$ from the tunnel outlet (see Fig. 1). High-water erosion marks in channel banks and ice blocks deposited on elevated channel surfaces were used to define the cross-sectional flow area. Average velocity, assuming uniform and steady flow, was estimated using the Manning-Strickler relation (Henderson, 1966; Church and Gilbert, 1975):

$$
v=R^{2 / 3} S^{1 / 2} / 0.038 D^{0.167}
$$

$R$ is the hydraulic radius (m), $S$ is the bed slope for a $100 \mathrm{~m}$ channel reach, and $D$ is the average intermediate axis (m) of the ten largest particles in the river bed - a surrogate measure of flow resistance (Manning's " $n$ ") assuming the bed material is the dominant roughness element. Hydraulic parameters and flow reconstructions for the two selected reaches are given in Table I. At $1 \mathrm{~km}$, the average velocity was $5.4 \mathrm{~m} \mathrm{~s}^{-1}$ and the estimated peak discharge was $1534 \mathrm{~m}^{3} \mathrm{~s}^{-1}$. At $12 \mathrm{~km}$ down-stream, the velocity and peak discharge were $5.5 \mathrm{~m} \mathrm{~s}^{-1}$ and $1155 \mathrm{~m}^{3} \mathrm{~s}^{-1}$, respectively. The down-stream attenuation of discharge is about $25 \%$ and is due to short-term storage of flood waters in both temporary ponds and a permanent, valley-bottom lake between the two sites. This is comparable to attenuation rates found during other outburst floods (Clarke and Waldron, 1984) and for artificial dam failures (Costa, 1988).

The estimates of flow resistances implicit in these calculations are 0.041 and 0.047 (see Table I). The Strickler relation used to compute flow resistance is based on particle roughness $(D)$ which was perceived to be the dominant form of resistance in the channel during outburst flooding. Jarrett (1984) analyzed data from several coarse-grained streams in Colorado and derived a relation for flow resistance based on form roughness:

$$
n=0.39 S^{0.38} R^{-0.16} \text { (fps units). }
$$

As a check on flow resistance, velocities were recomputed using the above relation which produced results that were between 14 and $23 \%$ less than those velocities derived from the Manning-Strickler equation. Hence, the peak-discharge values in Table I may be somewhat high. Observations of standing waves and well-developed hydraulic jumps during both floods indicate that flow conditions in the channel were fully turbulent and supercritical which would produce a Froude number at or greater than 1.0. This condition is satisfied only at the higher velocities reported in Table I. The implication is that, while the assumption of steady flow is supect and the results using Manning-Strickler may be somewhat high, hydraulic conditions in the channel are consistent with peak discharges that approach $1500 \mathrm{~m}^{3} \mathrm{~s}^{-1}$ at $1 \mathrm{~km}$ down-stream from Fyles Glacier and about $1100 \mathrm{~m}^{3} \mathrm{~s}^{-1}$ at $\mathrm{km} 12$.

A physical-based model developed by Clarke (1982) to determine peak flow from ice-dammed lakes may also be applied. The model is sensitive to specification of lake temperature and roughness of the ice tunnel. An average lake temperature of $4^{\circ} \mathrm{C}$ was assumed to be a reasonable value for late October. The Manning roughness coefficient could not be measured directly as the tunnel was inaccessible after both outburst floods, but a commonly used value of $n=0.12 \mathrm{~m}^{-1 / 3} \mathrm{~s}$ was assumed, corresponding to a rough tunnel. The ice thickness at the seal was assumed to be $85 \mathrm{~m}$ (the height of ice above the tunnel entrance), while tunnel length was around $1860 \mathrm{~m}$. Full results of the model have been given by Jones and others (1985). Assuming that there was no creep closure of the tunnel and that only the top $10 \mathrm{~m}$ of the entire lake plus the remaining volume in the west basin drained, the model converges on a peak-discharge estimate of $483 \mathrm{~m}^{3} \mathrm{~s}^{-1}$. By comparison with other methods which range between 1100 and $1700 \mathrm{~m}^{3} \mathrm{~s}^{-1}$ (Table II), this estimate is much lower.

The anomalously low value for the physical model is likely due to four factors: assumed estimates of lake-water temperature and tunnel roughness, the initial volume involved with lake drainage, and the time required for 


$\begin{array}{ccccccccc}\text { Section }^{\dagger} & \text { Area } & R & S & D & n & v & Q & F r \\ & \mathrm{~m}^{2} & \mathrm{~m} & & \mathrm{~m} & & \mathrm{~m} \mathrm{~s}^{-1} & \mathrm{~m}^{3} \mathrm{~s}^{-1} & \\ \mathrm{~km} \mathrm{1} & 284 & 3.15 & 0.0104 & 1.5 & 0.041 & 5.4 & 1534 & 0.97 \\ \mathrm{~km} \mathrm{12} & 210 & 2.76 & 0.0170 & 3.5 & 0.047 & 5.5 & 1154 & 1.06\end{array}$

Note: measurements are for the average of three cross-sections over a $50 \mathrm{~m}$ channel reach.

* $R$, hydraulic radius; $S$, slope; $D$, roughness diameter; $n$, roughness coefficient; $v$, velocity;

$+Q$, peak discharge; $F r$, Froude number.

+ Section names refer to distance down-stream from the outlet of the Fyles Glacier ice tunnel.

TABLE II. ESTIMATES OF PEAK DISCHARGE FOR THE FIRST OUTBURST FLOOD IN NOEICK RIVER VALLEY

\section{Method}

Mean discharge

Discharge

Comment

540

Peak discharge

$Q_{\max } / Q_{\text {mean }}$

$1080-3240$

Clague-Mathews

$1680 \pm 380$

\begin{abstract}
Manning-
Strickler

$1 \mathrm{~km} 1534$

$12 \mathrm{~km} 1155$
\end{abstract}

Clarke Model

483 time $24 \mathrm{~h}$ mean $Q$ factor 1.59
Based on a drainage

Based on a ratio of two to six times the

Glacial Lake Missoula excluded, new data added, bias correction

Resistance coefficient based on particle size

Assumed " $n$ " of 0.12 and lake-water temperature of $4^{\circ} \mathrm{C}$

drainage. Measurements of average lake-water temperature made during the summer of 1984, and surface-water temperature following the first drainage, are consistent with that used in the model. Lake-water temperature would need to be several degrees higher to achieve the higher discharges. Without direct measurement or indirect calibration, tunnel roughness remains unknown. A less rough tunnel is possible but unlikely. The possibility exists that there was more than the assumed $70 \%$ of lake volume involved in tunnel enlargement during the first flood. Specification of the entire lake volume in the model yields a discharge that is $41 \%$ larger $\left(640 \mathrm{~m}^{3} \mathrm{~s}^{-1}\right)$. Finally, the length of time required for lake drainage in the model is much longer $(79 \mathrm{~h})$ than direct observations would suggest. Shorter drainage times would be coincident with the presence of pre-existing sub- and englacial tunnel segments of Fyles Glacier - a condition which is common to many glaciers (cf. Stenborg, 1969; Shreve, 1972) and quite probable in this case given that the outlet tunnel for both floods was the same as that used by normal melt-water flows.

Using the few measurements that were available, high-water marks in down-stream reaches following the August 1986 flood were higher in constricted bedrock channels than the first flood, indicating a greater peak discharge. Several factors explain this: (1) the moraine dam in Ape Lake was already breached, allowing the entire $46 \times$ $10^{3} \mathrm{~m}^{3}$ to be released all at once; (2) tunnel enlargment may have required less energy due to the presence of pre-existing tunnel segments; (3) valley-bottom depressions between $\mathrm{km} 1$ and 12 which acted as intermediate storage ponds were either eroded or filled with sediment; (4) channel and infiltration storage is lower during the mid-summer high-flow period; and (5) much of the vegetation on the flood plain was removed by the first flood, hence, resistance to flow would have been less.

\section{GENERAL DISCUSSION AND CONCLUSIONS}

Recent outburst flooding at Ape Lake is just one of several examples over the last 50 years of ice-dam failures in the glacierized parts of British Columbia. At Ape Lake, a terminal moraine which acted as a mid-basin dam appears to have reduced the magnitude but increased the duration of the first outburst flood in October 1984. The now permanent breach in the moraine allowed for the full $46 \times$ $10^{6} \mathrm{~m}^{3} \mathrm{~s}^{-1}$ of lake water to be released continuously during the second flood in August 1986. It is not known if excessive precipitation or other meteorological conditions at the lake were important factors contributing to the first flood occurrence, but records from nearby climate stations suggest that they were not. Dam failure then is related to the continuous thinning and lateral retreat of Fyles Glacier - estimated at between 15 and $18 \mathrm{~m} \mathrm{year}^{-1}$ over the last 120 years (Jones and others, 1985; Desloges, unpublished) and the still unknown subglacial plumbing of Fyles Glacier.

Indirect estimates of peak-flood magnitudes approach $1100 \mathrm{~m}^{3} \mathrm{~s}^{-1}$ for alluvial reaches in upper Noeick River. This is approximately twice the estimated average outburst flood magnitude and three times as large as a climate-derived flood with a 100 year recurrence interval for a basin of this size (Jones and others, 1985). Observations on flow type during the first flood, channel morphology, and erosional evidence are consistent with the assumed hydraulic conditions necessary for the estimated flood velocities used in the slope-area method. The same approach for a cross-section closer to the outlet tunnel of Fyles Glacier yields a peak flow that is as much as 33\% higher. Much of the flow attenuation between these two sites is a function of water storage in the channel and flood plain of Noeick River.

It is interesting to note that the original Clague-Mathews formula yields an estimate of peak flow for the first flood very near that estimated for the down-stream reaches of Noeick River $(980 \pm 190)$ and appears to have worked well when used in other studies. Two factors may explain this. First, the addition of new data points to the Clague-Mathews data set does not appear to change appreciably the exponent $b$ of the best-fit curve (i.e. $b=0.67$ in the original relation). However, the fewer cases available in the original functional relation yielded a lower scatter of observations and reduced bias, thereby better matching some observations of peak outburst flows. Secondly, some of the unexplained variance of the regression fit is undoubtedly related to the methods employed for estimating actual peak discharge and is dependent on where in the channel network discharge measurements are made. Stream gauges, most of which are located some distance down-stream and prone to less precision or outright failure during large floods, may not give a good indication of actual flood magnitude nearer the source. Many studies have relied on these down-stream gauges. Flow estimates using water-level changes in the lake basin are only as good as the degree to which lake bathymetry is known. Finally, in some studies peak flows are derived from indirect methods, such as the slope-area technique, which are themselves subject to error. The evidence presented here suggests close correspondence 
between the slope-area method and the unbiased ClagueMathews formula for a site $1 \mathrm{~km}$ down-stream from Fyles Glacier.

After each draining of Ape Lake, the unsupported and near-vertical ice dam was subject to ice falls which have contributed to the rapid recession of Fyles Glacier along the lake margin (Fig. 2b). This has now allowed for the formation of a stream channel around the margin of the ice dam and a reduction in the level of the lake. In the absence of any significant advance of Fyles Glacier, melting of the ice margin by the stream will lead to lower lake levels and eliminate further outburst flooding. Adjustments of Noeick River, then, will be confined to normal fluvial processes.

The presence of undamaged trees on the Noeick River flood plain prior to the first flood, some as old as 300 years, indicates that the two recent events are unique in the Little Ice Age history of the basin. Recent studies in the area (Ryder and Thomson, 1986; Desloges and Ryder, unpublished) reveal that many glaciers such as Fyles Glacier may have been fully advanced as early as the twelfth century and remained close to these positions until the late nineteenth century. The full Ape Lake then would only have existed for the last $80-100$ years.

\section{ACKNOWLEDGEMENTS}

We should like to thank $R$. Lenci and $R$. Clarke (Crown Forest Co.) and R. Thomas and E. Beattle (British Columbia Forest Service) for continuing assistance in monitoring Ape Lake and for field support. M. Cantwell assisted in the survey of water levels at Ape Lake and down-stream surveys of Noeick River. Mr A. Port of the Kootenay Mountaineering Club completed our observations on refilling rates following the first flood. We thank G. Clarke and M. Maxwell for results from the outburst flood model. The manuscript was kindly reviewed by $\mathrm{M}$. Church. This study was funded from NSERC operating grant A7950 to $M$. Church, a grant from the University of British Columbia emergency fund, and by contract support to D. Jones and K. Ricker from the Geological Survey of Canada.

\section{REFERENCES}

Church, M. and R. Gilbert. 1975. Proglacial fluvial and lacustrine environments. In Jopling, A.V. and B.C. McDonald, eds. Glaciofluvial and glaciolacustrine sedimentation. Tulsa, OK, Society of Economic Paleontologists and Mineralogists, 22-100. (Special Publication 23.)
Clague, J.J. and W.H. Mathews. 1973. The magnitude of jökulhlaups. J. Glaciol., 12(66), 501-504.

Clarke, G.K.C. 1982. Glacier outburst floods from "Hazard Lake", Yukon Territory, and the problem of flood magnitude prediction. J. Glaciol., 28(98), 3-21

Clarke, G.K.C. and D.A. Waldron. 1984. Simulation of the August 1979 sudden discharge of glacier-dammed Flood Lake, British Columbia. Can. J. Earth Sci., 21(4), 502-504.

Costa, J.E. 1988. Floods from dam failures. In Baker, V.R., R.G. Kochel, and P.C. Patton, eds. Flood geomorphology. New York, John Wiley and Sons, 439-463.

Desloges, J.R. Unpublished. Paleohydrology of the Bella Coola River basin: an assessment of environmental reconstruction. (Ph.D thesis, University of British Columbia, 1987.)

Desloges, J.R. and J.M. Ryder. Unpublished. Neoglacial history of the Coast Mountains near Bella Coola, British Columbia.

Ferguson, R.I. 1986. River loads underestimated by rating curves. Water Resour. Res., 22(1), 74-76.

Gilbert, R. and J.R. Desloges. 1987. Sediments of ice-dammed, self-draining Ape Lake, British Columbia. Can. J. Earth Sci., 24(9), 1735-1747.

Henderson, F.M. 1966. Open channel flow. New York, MacMillan.

Jarrett, R.D. 1984. Evaluation of methods estimating palaeofloods on high-gradient streams. (Paper presented at the American Geophysical Union Fall Meeting, San Francisco, California.)

Jones, D.P., K.E. Ricker, J.R. Desloges, and M. Maxwell. 1985. Glacier outburst flood on the Noeick River: the draining of Ape Lake, British Columbia, October 20, 1984. Geol. Surv. Can. Open File Rep. 1139.

Miller, D.M. 1984. Reducing transformation bias in curve fitting. Am. Stat., 38(1), 124-126.

Post, A. and L.R. Mayo. 1971. Glacier dammed lakes and outburst floods in Alaska. U.S. Geol. Surv. Hydrol. Invest. Atlas 455.

Ryder, J.M. and B. Thomson. 1986. Neoglaciation in the southern Coast Mountains of British Columbia: chronology prior to the late Neoglacial maximum. Can. J. Earth Sci, 23(3), 273-287.

Shreve, R.L. 1972. Movement of water in glaciers. $J$. Glaciol., 11(62), 205-214.

Stenborg, T. 1969. Studies of the internal drainage of glaciers. Geogr. Ann., 51 A(1-2), 13-41.

Sturm, M., J. Beget, and C. Benson. 1987. Observations of jökulhlaups from ice-dammed Strandline Lake, Alaska: implications for paleohydrology. Binghamton Symposia in Geomorphology. International Series, 18, 79-93. 